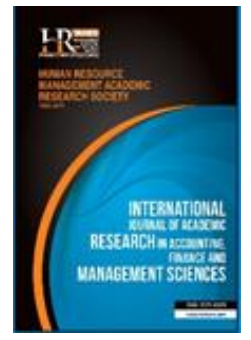

International Journal of Academic Research in Accounting, Finance and Management Sciences

Vol. 8, No.4, October 2018, pp. 16-20

E-ISSN: 2225-8329, P-ISSN: 2308-0337

(C) 2018 HRMARS

www.hrmars.com

To cite this article: Deannes Isynuwardhana, D., Surur, G.N.I. (2018). Return Analysis on Contract Option Using Long Straddle Strategy and Short Straddle Strategy with Black Scholes, International Journal of Academic Research in Accounting, Finance and Management Sciences 8 (4): 16-20.

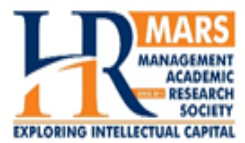

http://dx.doi.org/10.6007/IJARAFMS/v8-i4/5181 (DOI: 10.6007/IJARAFMS/v8-i4/5181)

\title{
Return Analysis on Contract Option Using Long Straddle Strategy and Short Straddle Strategy with Black Scholes
}

\section{Deannes ISYNUWARDHANA ${ }^{1}$, Gisyari Nurul Istiqamah SURUR ${ }^{2}$}

1,2Telkom University Indonesia, E-mail: deannes@telkomuniversity.ac.id

\begin{abstract}
Investment in the capital market never had any risk. The greater the risks level of an asset, the greater the risk of the asset, and vice versa. One of the risks is the fluctuated stock price movement. Derivatives instruments can be used to mitigate the risk of investment. One of the derivatives instruments traded in Indonesia is option contract. This study aimed to analyze the return on contract option using long straddle strategy and short straddle strategy with Black Scholes model. In addition, this study also compares which strategies are better between the two strategies. The sample in this research was determined by purposive sampling method to obtain 5 companies as a sample. Based on the results, long straddle strategy is the best strategy because the profits are unlimited and the loss is limited to call and put premium. For investors who want to invest in the derivatives market, in particular contracts option investors should look at the movement of stock prices. If the movement of stock increased or decreased drastically, then the best would be long straddle strategy. In addition, investors should choose an option contract with a validity period of 2 months because of the potential to provide greater profits.
\end{abstract}

Key words

Derivative, contract option, long Straddle, short straddle, Black Scholes

Received: 20 Nov $2018 \quad$ (c) The Authors 2018

Revised: 1 Dec 2018 Published by Human Resource Management Academic Research Society (www.hrmars.com)

Accepted: 12 Dec 2018 This article is published under the Creative Commons Attribution (CC BY 4.0) license. Anyone may reproduce, distribute, translate and create derivative works of this article (for both commercial and noncommercial purposes), subject to full attribution to the original publication and authors. The full terms of this license may be seen at: http://creativecommons.org/licences/by/4.0/legalcode

\section{Introduction}

Investments made by investors in the capital market can not be separated from the risks. The erratic movement of stock values can be a risk for investors. The greater level of risk of an asset, the higher the level of expected return of the asset, and vice versa. Stock price movements can be seen in the Composite Stock Price Index (IHSG). IHSG is an index that uses all issuers on the Indonesia Stock Exchange (IDX) to be used as components in calculating the price index. The following are the movements of the IHSG in 20152017:

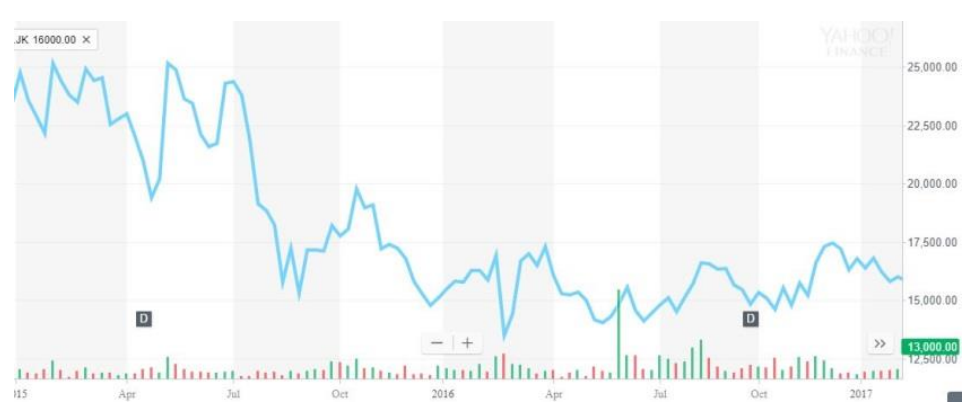

Figure 1. IHSG Stock Movement year 2015-2017 
Figure 1 illustrates the risk of decreasing value of existing stock investments in 2015-2017. There was a significant decrease in the IHSG value from May 2015 to August 2015, a decrease of 9,862 points from the index price of 25,155.30 to 15,293.50. In October 2015 to February 2016 there was a decrease in the IHSG value of 6,288.5 points from index price of 19,771.70 to 13,482.80. In March 2016 until the beginning of 2017, the IHSG experienced a decreasing value. The fluctuating of IHSG showing a high level of risk, thus there is a need for investors to reduce the level of risk. In the concept of investment, it called hedging.

Option trading strategies can be grouped into five, namely: naked, hedge, straddle, combination and spread strategies. Naked strategy is an option trading strategy that selects one of four positions, namely as a call option buyer, call option seller, put option buyer or put option seller. The hedge strategy which is an option trading strategy that selects two positions from the existing option position by having shares that become the benchmark. There are two types of hedge strategies, namely: covered call writing strategy and protective put buying strategy. The straddle strategy is a strategy carried out by selling or buying, either in the form of put options or call options that have the same stock benchmark, expiration date, and strike price. Straddle strategy can be done in two ways, namely: long straddle strategy and short straddle strategy. A combination strategy is a strategy that combines put options and call options with the same stock benchmark, but different expiration dates and strike prices. Spread strategy is a strategy that buys an option class that is financed entirely by the sale of other options. There are four variations of spread strategies, namely: horizontal spreads (time spreads), vertical spreads (price spreads), bull spreads, and bearish spreads (Tandelilin, 2010).

This study selects one of the five options trading strategies available which is straddle strategy. The straddle strategy was chosen because this strategy produces the most profit for investors if the stock price goes up or down through the break even point and the maximum loss obtained by the investor limited to the value of selling or buying the call and put. Therefore would be minimizing the risk.

The straddle option contract can be done in two ways, namely the long straddle strategy and the short straddle strategy. This strategy is used to provide input to investors as one of the considerations regarding which strategy is better to deal with the risk of stock price movements that always fluctuate. In this study, the author will analyze the comparison of returns on option contracts using the strategy. This study will analyze the returns of option contracts with a validity period of 1 month, 2 months and 3 in 2016 .

\section{Materials and Methodology of research}

The population in this study are companies listed in Indonesia Stock Exchange (IDX), using purposive sampling there were five companies that met the requirements. These companies are PT Astra International Tbk (ASII), PT Bank Central Asia Tbk (BBCA), PT Indofood Sukses Makmur Tbk (INDF), PT Telekomunikasi Indonesia Tbk (TLKM), and PT HM Sampoerna Tbk (HMSP).

Black-Scholes Model

The Black Scholes model is a theoretical pricing option model (call option and put option) developed by Fischer Black and Myron Scholes. [5]

a. Black Scholes Formula [8]

$$
C=S N\left(d_{1}\right)-X(e)^{-(r) T} N\left(d_{2}\right)
$$

where:

$$
\begin{aligned}
& d_{1}=\frac{\operatorname{In}(S / R)+(r+, 05 \sigma 2) T}{\sigma \sqrt{T}} \\
& d_{2}=d_{1}-\sigma \sqrt{T}
\end{aligned}
$$

Where:

$\mathrm{C}=$ call option;

$\mathrm{p}=$ put option;

$\mathrm{S}=$ stock price;

$\mathrm{X}=$ strike price;

$r=$ interest rate. 
$\mathrm{T}=$ remaining time until the expiration date

$\mathrm{e}=2,718282$

$\sigma=$ stock price standard deviation

$N()=$. cumulative density function of $d_{1}$ and $d_{2}$

\section{b. Put Option}

Determine the price of put option using the following formula (Tandelilin, 2010):

$c_{\text {put }}={ }^{X} /\left(e^{r t}\right)-\left(S-C_{\text {call }}\right)$

Where:

$C_{\text {put }}$ = put option;

$C_{\text {call }}=$ call option;

$\mathrm{X}=$ strike price;

$\mathrm{S}=$ stock price;

$r=$ interest rate;

$\mathrm{t}=$ Expiration date (in one year);

$\mathrm{e}=2,718282$.

\section{Option Contract Returns}

Returns are profits obtained by companies, individuals, and institutions as the gain of investment decision. Yields can also be interpreted as investment returns, either through interest or dividends (Fahmi, 2015). Returns from long straddle and short straddle strategies can be calculated by the formula (Sinclair, 2010):

Returns $=S-X-(C+P)$ if $S>X$

and

Return $=X-S-(C+P)$ if $S<X$

\section{Results and Discussions}

\subsection{Return Option Contract ASII}

Based on the results, it can be known that yields in 2016 are varied. For ASIl at the time of 1 month maturity has a total profit of $4,554.12$ and the average profit is 379.51 . At the maturity of 2 months has a total profit of $6,656.42$ and the average profit is 554.70 . While at the maturity of 3 months has a total profit of $6,227.53$ and the average profit is 518.96. The result show that yields for the maturity of 1 month, 2 months, and 3 months, mostly are profitable, with some losses that are not significant compared to the profits achieved by investors. Investor profits are caused by the high deviation of the index price by the exercise price. The best strategy used for ASII Shares is a long straddle strategy for maturities of 1 month, 2 months and 3 months. The long straddle strategy is used because the return value obtained for each month at the maturity of 1 month, 2 months and 3 months exceeds the minimum and maximum limits calculated. This is in line with the long straddle strategy concept, in which that the benefits obtained are not limited while the losses are equal to call and put premiums.

\subsection{Return Option Cotract BBCA}

The result show that the returns in 2016 is vary. For BBCA at the time of 1 month maturity has a total profit of $4,208.25$ and the average profit is 350.69 . At the maturity of 2 months has a total profit of $5,840.00$ and the average profit is 487.67 . While at the maturity of 3 months has a total profit of $4,944.53$ and the average profit is 412.04 . The result also show that mostly at the maturity 1 month, 2 months, and 3 months are profitable. This condition can be caused by high deviation of the index price by the exercise price. It can be concluded that related to BBCA, long straddle strategy would be the best strategy for all maturity period. 


\subsection{Return Option Contract INDF}

Based on the results, it can be known if the returns in 2016 are varied. For INDF at the time of 1 month maturity has a total profit of $4,558.66$ and the average profit is 379.89 . At the maturity of 2 months has a total profit of $6,656.38$ and the average profit is 554.70 . While at the maturity of 3 months has a total profit of 6,221.76 and the average profit is 518.48. Similar with ASII and BBCA, the result also show that long straddle strategy would give higher return than short straddle. Thus the best strategy for BBCA would be long straddle strategy.

\subsection{Return Option Contract TLKM}

Based on the results, it can be known if the returns in 2016 are varied. For TLKM at the time of 1 month maturity, the total profit is 4,866.66 and the average profit is 405.55 . At the maturity of 2 months has a total profit of 7,182.30 and the average profit is 598.52. While at the maturity of 3 months has a total profit of 6,967.71 and the average profit is 580.64 . The best strategy for TLKM would be long straddle strategy since it gave higher return than short straddle strategy.

\subsection{Return Option Contract HMSP}

Based on the results, it can be known if the returns in 2016 are varied. For HMSP at the maturity of 1 month, the total profit is 818.55 and the average profit is 68.21 . At the maturity of 2 months has a total profit of 74.87 and the average profit is 6.24 . While at the time of maturity 3 months suffered a loss of $(3,224.36)$ and the average loss was $(270.36)$. Investors' profits are caused by the high index price deviation with the exercise price, while investor losses are caused by the low index price deviation with the exercise price. The strategy used for HMSP is the long straddle strategy both for 1 month and 2 month. Different with other maturity, the 3 month maturity of HSMP suffer a loss in this strategy.

\section{Conclusions}

Based on the results and discussion that the author has outlined, the following conclusions can be drawn:

1) Option contract yields with a validity period of 1 month, 2 months and 3 months in 2016 using the long straddle strategy and short straddle strategy to experience profits, except for HMSP for maturity of 3 months.

a) At the time of the 1 month maturity of ASII's profit amounting to Rp.4,554.12, BBCA's profit amounted to Rp.4,208.25, INDF's profit amounted to Rp.4,558.66, TLKM's profit amounted to Rp.4,866.66, and HMSP's profit amounted to Rp818.55.

b) At the maturity of 2 months ASII's profit is Rp.6,656.42, BBCA's profit is Rp.5,840.00, INDF's profit is Rp.6,656.38, TLKM profit is Rp.7,182.30, and HMSP profit is Rp74, 87.

c) At the maturity of 3 months ASII's profit is Rp.6,227.53, BBCA's profit is Rp.4,944.53, INDF's profit is 6,221.76, TLKM profit is Rp.6,967.71, and HMSP loss is Rp.3,244, 36 .

2) The use of the long straddle strategy for the return of option contracts with validity periods of 1 month, 2 months and 3 months in 2016 is more profitable compared to the short straddle strategy. In accordance with the 2016 market trend, the long straddle strategy is more appropriate when the trend of market prices increases or decreases drastically.

\section{References}

1. Bodie, Z., Kane A., dan Marcus A.J. (2014). Manajemen Portofolio dan Investasi. Jakarta: McGrawHill Education (Asia) dan Salemba Empat.

2. Fahmi, I. (2015). Pengantar Teori Portofolio dan Analisis Investasi. Bandung: Alfabeta.

3. Financefinance.yahoo.com. (2018). Dipetik Februari 3, 2018, dari https://finance.yahoo.com/chart/AALI.JK\#eyJpbnRIcnZhbCI6IndIZWsiLCJwZXJpb2RpY2I0eSI6MSwidGItZVVu aXQiOm51bGwsImNhbmRsZVdpZHRoljo2LjUzMDQ4NzgwNDg3ODA0OSwidm9sdW1IVW5kZXJsYXkiOnRyd WUsImFkail6dHJ1ZSwiY3Jvc3NoYWlyljp0cnVILCJjaGFydFR5cGUiOiJsaW5IliwiZXh0ZW5kZWQ 
4. Halim, A. (2015). Analisis Investasi di Aset Keuangan. Jakarta: Mitra Wacana Media.

5. Herlianto, D. (2013). Manajemen Investasi Plus Jurus Mendeteksi Investasi Bodong. Yogyakarta: Gosyen Publishing.

6. Sinclair, E. (2010). Option Trading: Pricing and Volatility Strategies and Techniques. Hoboken, New Jersey, United States: John Wiley \& Sons.

7. Sutedi, A. (2012). Produk-Produk Derivatif dan Aspek Hukumnya. Bandung: Alfabeta.

8. Tandelilin, E. (2010). Portofolio dan Investasi. Yogyakarta: Kanisius. 